\title{
THE INFLUENCE OF ANDROID-BASED ROLE PLAYING LEARNING MODEL TOWARD STUDENTS' MOTIVATION IN SPEAKING SKILL
}

\author{
Zailin Ayu ${ }^{1}$, Ida Nuraida ${ }^{2}$ \\ University of Banten Jaya \\ Serang, Indonesia \\ zailinayu22@gmail.com¹, idanuraida@gmail.com²
}

\begin{abstract}
This study aims to analyze the influence of Android-based role playing learning models towards students' motivation in speaking skills. This study used a quasi-experimental method with the Nonequivalent Control Group Design. The sample of this study consisted of two classes. The research instrument used tests and questionnaires. Based on the results of the average value of the experimental class pretest class is 59.25 and posttest is 72.95 has increased by 13.70 while the average value of the pre-test control class is 68.3 and post-test is 58.75 experienced a decrease of 9.55. The average questionnaire result data was 89.5 and it was concluded that there were differences in student motivation before and after learning with Android-based role playing models. Learning using Android-based has an influence on learning motivation of students in class X TKJ by 53\% with the results of $t$-table $>t$-count (5.35 > 2.06), then the hypothesis is accepted. At the end of this study, it is hoped that learning based on Android can be used as an alternative in learning speaking skills.
\end{abstract}

Keyword: Role Playing, Andoid, Student's Motivation.

\section{INTRODUCTION}

one of the ideals of Indonesia, this is stated

At present, the world is entering the era of the industrial revolution 4.0 or the fourth world industrial revolution where technology has become the basis in human life. All things become unlimited and unlimited due to the development of the internet and digital technology. This era has influenced many aspects of life both in the economic, political, cultural, artistic and even to the world of education.

Educating the life of the nation is 
Universitas Banten Jaya

in Preamble of 1945 Constitution of the

Republic of Indonesia the fourth alenia

which reads:

...Pursuant to which, in order to form a Government of the State of Indonesia that shall protect the whole people of Indonesia and the entire homeland of Indonesia, and in order to advance general prosperity, to develop the nation's to intellectual life, and to contribute to the implementation of the world order based on freedom, lasting peace, and social justice, Indonesia's National Independence show be laid down in a constitution of the State of Indonesia, which is to 
be established as the State of the Republic of Indonesia...

One way to educate the nation's life is through education. In the 2018 National working meeting, Sri Mulyani at the time became 'keynote speaker' she said the progress of a country to pursue the backwardness is very dependent on three factors namely education, quality institutions and infrastructure readiness (Ristekdikti, 2018).

Based on the statement above, it can be seen that education is a pillar major in the progress of a country. In addition, education is very important to improve quality of human resources. Increasing the quality of human resources is also needed quality education. In Law No. 20 of 2003 said that "Education means conscious and well-planned effort in creating a learning environment and learning process so that learners will be able to develop their full potential for acquiring spiritual and religious strengths, develop self-control, personality, intelligence, morals and noble character and skills that one needs for him/herself, for the community, for the nation, and for the State”.

As for the relationship between the world of education and the industrial revolution 4.0, the world of education is demanded to keep abreast of rapidly developing technology and utilize information and communication technology as more and all-powerful facilities to facilitate the learning process. In addition, it is expected that by the use of information and communication technology learning mindsets become student centered rather than teacher centered.

The use of technology is expected can increase teacher creativity in student interest in learning because of the process of conventional learning deemed less pleasant and fairly calculated monotonous. In addition, learning is only centered on the teacher and the book will make students bored with classroom learning (Destiana, The influence of technology information based android (smartphone) in educational of industry 4.0, 2019).

The role of technology in the world of education is inevitable. The government has also set the needs for inside technology various laws and regulations. One of them is listed in Permendiknas No. 16/2007 concerning Academic Qualification Standards and Teacher Competency, Pedagogical Competence of SMA / SMK teachers point 5 said that "High school / vocational teachers must utilize information and communication technology for the benefit of learning". Emphasized in Permendiknas No. 41 of 2007 concerning Process Standards, in accordance with Graduates Competency Standards and 
Content Standards, the learning principle used in point 13 states that "Utilization of information and communication technology to improve the efficiency and effectiveness of learning".

Based on legislation that has been issued by the government, states that a teacher is required to be able to adapt to rapidly developing technology so that the learning tools and teaching and learning process seem innovative and creative. As mobile technology has entered into the mainstream society, it influences people's lifestyle in recent years. It changes people's way of work, study, and daily act. (Calimag, Miguel and Conde, 2014) state that mobile devices can facilitate human interaction and access to information resources anytime and anywhere.

People use these smart phones, for instance Android smartphones in the various ages. Since mobile technology develops, it creates new opportunities for improving learning experience of students at all level of education. It facilitates students to access educational resources without need to be present at the working environment. Mobile devices are a useful tool and a way to access last recent events in the classroom (Calimag, Miguel and Conde,2014).

The students can get more access to use those applications to give new experience in learning environment where they are given more opportunity to learn outside the classroom (Anderson, 2008). As the development of technology today has given many advantages for people's life style, many experts and educators of institution believe that technology can be employed in educational sectors to support the teaching and learning activities.

Technology has a significant role in teaching and learning process. Bajcsy (2002) says that technology in teaching and learning as an enabler and suggests that technology can work to help organize and provide structure for material to students; help students, teachers, and parents interact, anytime and anywhere; facilitate and assist in the authentication and prioritization of Internet material; and simulate, visualize, and interact with scientific structures, processes, and models.

Related to speaking, technology can serve as media for learning speaking skill. By implementing the use of technology in learning speaking in the classroom, students will be motivated to learn more. Technology improves motivation to create authentic task to motivate, and it can be carried out by creating a reason from speaking in target language, and broadening the audience base.

Technology can also increase communication which equipped with audios, videos and activities that are 
boosting the learners ${ }^{\text {ee }}$ ability to speak. In this case, the students have opportunity to record their performance, they can be able to evaluate their performance and practice more. In the same line,

\section{Banares (2010) proposes the} benefits of recording the students ${ }^{\text {ee }}$ performance for example students have more speaking practices, the students pay more attention to pronounce the words since they will be listened to the rest of the group, motivation is high since the students are digital authors of the course content, shy students are not left behind. In this case, the students are able to recognize their speaking product. By recording their performance, the students will know what they do and what they need to improve their speaking skill.

One of learning technology that can be used is android based learning, where students can be use the application android whose content is in accordance with the subjects studied. Android is an operating system designed by Google on a Linux kernel basis to support the performance of touch screen electronic devices, such as tablets or smartphones.

Therefore, android is used with touch, swipe or knock on the gadget screen. Android is open source or free to use, modify, repair and distribute by software makers or developers. With the open source nature of the free technology companies using this OS without the license and free.

According to Troussasa, Krouskaa, and Sgouropoulou (2015) in their journal of Computer and Education, Vol. 114, No 10, entitled "Collaboration and fuzzy-modeled personalization for mobile learning based on higher education": Technological advances to facilitate the learning process and improve learning outcomes. Such technological advancements include the development of web-based educational environments and cellular applications, and the use of personal computers and mobile devices as learning tools.

At present, mobile devices, such as smartphones or tablets, have disrupted our daily lives beyond the use of personal computers. This journal presents Quiz Time, which is an intelligent mobile gamebased learning application that promotes personalized and collaborative learning. It combines entertainment even though it is a user-friendly interface along with the educational elements through the assessment and advancement of knowledge.

Besides, according to Hwang, Chen (2016) in the British Journal of Educational Technology Volume 48, Issue 4, titled "Influences of an inquiry-based ubiquitous gaming design on students' learning 
Universitas Banten Jaya

achievements, motivation, behavioral patterns, and tendency towards critical thinking and problem solving" that In this journal, and inquiry-based ubiquitous gaming approach was proposed.

The objective of the study was to enhance students' performances in in-field learning activities. Moreover, to show the advantages of the approach, an experiment was carried out to assess the effects of it on students' learning achievement, motivation, critical thinking, and problem solving. Furthermore, the students' behavioral patterns were investigated via content and sequential analysis methods. The experimental outcomes show that the approach promoted students' performances of learning achievement and intrinsic motivation.

The writer has conducted preliminary studies on Monday at $6^{\text {th }}$ January, 2020. The writer has observed the class and interviewed several students and English teacher. Based on the information obtained by the writer SMK Yaumin Cikande that the motivation to learn in $\mathrm{X}$ grade students' at SMK Yaumin Cikande on English subject is not optimal, especially in speaking skills. This was said not yet optimal because many students' complained with learning teachers methods, thus, students' felt bored and were easily sleepy when learning so as to make students' motivation decrease.

Speaking skill is one of the fourth skills in learning English. Speaking is a language skill that is developed in child life, which is produced by listening skill, and at that period speaking skill is learned. Based on Competence Based Curriculum speaking is one of the four basic competences that the students should gain well. It has an important role in communication. Speaking can find in spoken cycle especially in Joint Construction of Text stage (Departmen Pendidikan Nasional, 2004). In carrying out speaking, students face some difficulties one of them is about language its self.

$$
\text { According to Nuraida (2016) }
$$

speaking is a productive skill of language and the language learner should master it. Most people communicate orally each other by speaking, so it includes verbal communication. Speaking is a very demanding activity for all ages of learners which is used for oral communication. Speaking skill needs a lot of practice. Meanwhile, According to Pinter (2005), speaking practice starts with practicing and drilling set phrases and repeating models.

Therefore, the learners need to practice with different activities in classroom in order to encourage them to 
develop their proficiency in speaking so that they are able to communicate effectively. Most of students get difficulties to speak even though they have a lot of vocabularies and have written them well. The problems are afraid for students to make mistakes. In addition, Brown (2001) explains that in teaching speaking, teachers need to show the details of how to convey and negotiate the meaning of language. It means that the teacher should have good techniques to teach the students so that they can learn language easily. The objective of teaching speaking is to help learners communicate in the target language.

Naturally, student motivation is actually closely related to the desire of students to be involved in the learning process. The four stages of learning: initial engagement, process, disengagement, and re-engagement are shown to emit different processes of learning in students according to whether learning is intrinsically or extrinsically motivated. Intrinsic learning motivation involves inner desire to learn a more integrated set of skills stimulated by personal interest and curiosity.

Such students tend to utilize more of the available English language information and are more involved in the process of learning. Extrinsically motivated students are focused on achieving; external reward, in this case, proficiency in English entrance examinations to institutions of higher education. The emphasis is on the endproduct of education (Laurel, 2014).

The study of motivation in learning foreign languages cannot be separated from a study conducted by Gardner and Lambert (2001). Gardner examines motivation as a factors of different attitudes.

Two different sets of attitudes divide two basic types which Gardner and Lambert identified as instrumental orientation and integrative on motivation. Gardner developed a measurement of motivation students learning foreign languages.

According to Gardner (1972), the purpose of language teaching foreign is partly linguistic and partly non-linguistic. Linguistic purpose emphasizes the development of individual language skills which include reading, write, speak, and understand the foreign language. For proficiency purposes This language has many measuring tools that can be used (Santosa, 2017:4).

The difference in individual success in learning foreign languages has encouraged experts psychology conduct research to see what factors cause a person it works. Here are the three factors that most often get attention, namely aptitude, 
Universitas Banten Jaya

motivation (motivation), and opportunity (opportunity).

1) Ability to master English because of talent (Aptitude)

There are many people who are successful at work or succeed in their studies, however failed in learning a foreign language.

They have tried many times and spent a lot of time, but still having a lot of difficulties. Meanwhile there are some people who can absorb foreign words or

English words easily, understand grammar, and speak fluently in English. Many opinions say that the factor that distinguishes the two in mastering a foreign language is talent language. In an article written by Carroll with the title "Language Development in Children", published the opinions of several authors who say that language talent is the result innate nature that is difficult to change.

2) Ability to master English because of motivation (motivation)

In language acquisition, Gardner and Lambert determine motivation in two type, namely integrative motivation and instrumental motivation. Integrative motivation is that motivation.

Promoted by students who want to integrate with the culture and language they learn this is a great place for families full of motivation. Instrumental is motivation that is based on that hope by mastering a foreign language or English, one can achieve something like a better position or job. In addition, in this case language is a tool to achieve certain goals.

From of the two types of motivation above, according to Gardner and Lambert (2012), integrative motivation is more English or English. This is because individuals who have integrative motivation have a positive attitude towards language they understand, make him ready to do anything to be able to master the language.

This type of person actively practices and does not depend solely on books or teachers. They always looking to where to be able to open a foreign language or English through Broadcast on radio or television, and don't hesitate or shy to try to use it that language in conversation. For them, a foreign language is not a thing which is difficult because they are happy.

Thus, the ability to master the language English because Motivation is one important factor so that you are proficient in English. As supporting factors for successful learning English is best and is not hindered by age, condition and place.

3) Ability to Master English because of Opportunities (Opportunities)

Learn about opportunities, all learning activities are good, inside also outside the classroom, where students actively use the language that is being learned. Learning the 
Universitas Banten Jaya

ultimate goal of learning languages is using language to speaking, then opportunities that are trained are things that cannot be created by the teacher, but must also be sought by students.

Factors that cause the low activity and student learning outcomes in $\mathrm{X}$ grade SMK Yaumin Cikande are less attractive and monotonous teachers in delivering learning material. Teacher less applying learning that is interesting for students so students feel bored and less actively participating during class learning.

This results in activeness and student learning outcomes become low. Therefore, to overcome this, the teacher must do interesting learning and be able to stimulate so students can learn actively, thus, they can achieve maximum learning outcomes from existing learning, interesting and fun learning is through the application of role playing model based android.

Therefore, the writer want to apply the role playing model based android in the classroom. It expected that role playing model based android can motivate students in speaking skill so that the teaching and learning process can run well, both the teacher and the students can reach their goals; the teacher can deliver the materials, and the students can accept the materials given by the teacher well.
Role play is one of the best techniques to make students speak. This technique is very useful for developing the interpersonal skills of learners, for example, in role play activities a teacher gives a role to students and invites them to act as a police, hotel reception, doctor, etc by giving them a scenario.

Perhaps, in other session, the teacher also could give an opportunity to the students to create another narration, ideas for dialogue or scenario. As Kayi (2006) mentioned before, in role play activities students pretend that they are in a various social contexts and have a variety of social roles. The definition of Role play may vary from one expert to another. Ladousse (2010) defines:

"The word 'role' is they play apart (either their own or somebody else's) in a specific situation. The word 'play' means the role is taken on in a safe environment in which students are as inventive and playful as possible. A group of students carrying out a successful role play in a classroom has much in common with a group of children playing school, doctors, and nurses."

In this study, the role playing learning model was applied in English subjects. Where all students was directed through scenarios of how the implementation of the 
Universitas Banten Jaya

teaching and learning process in real situations through role playing.

Role playing learning that carried out in the teaching and learning process that is android-based role playing learning by using applications that support the process of learning English.

The application to be used is the Let's Learn English application. Let's Learn English is a new course for English learners. Certified American English teachers designed the course for beginners. The course contains 52 lessons. Let's learn English application is equipped with features:

1. Each lesson includes instructions in speaking. Each lesson has instructions to practice how to pronounce the correct word and how to speak correctly.

2. Vocabulary and writing. Each lesson has vocabulary and translation lines written in English, according to the conversation in the video.

3. Videos that show the lives of young Americans. Videos that are displayed attractively and are demonstrated directly by native speakers from America.

4. There are also worksheets that can be printed. There is a worksheet that can be used as an exercise and test the ability of our knowledge of the vocabulary in the conversation on the video.

5. Assessment and lesson plans for each English student and teacher. Students can learn how to speak according to their spelling and students can judge for themselves the extent of their speaking skills. In addition, teachers can also give assignments from worksheets contained in this application. The teacher can also adjust the material in the lesson plan and then this application as a learning medium so that students feel more interested and not monotonous.

6. American English level one and level two with many lessons to listen to. This application has a certain level so that students can measure their vocabulary mastery and speaking skills.

\section{English Features English: 6 minutes} English and English We Speak is great for learning. This application contains a video which is played by several native speakers.

8. English test is also important for students who exercise. With the practice exercises, students can improve vocabulary knowledge and speaking skills.

9. Video library is supported. The videos in this application are saved according to the lesson, and can be downloaded. 
10. Online Radio helps students improve English listening skills. Students listening to this video are expected to improve their speaking skills, because this video is played directly by native speakers from America.

Here are some views of the Let's Learn

English application that used by writer:

\section{Figures2.1}

\section{The let's learn English Application}

Fixed bug on Android 9.0

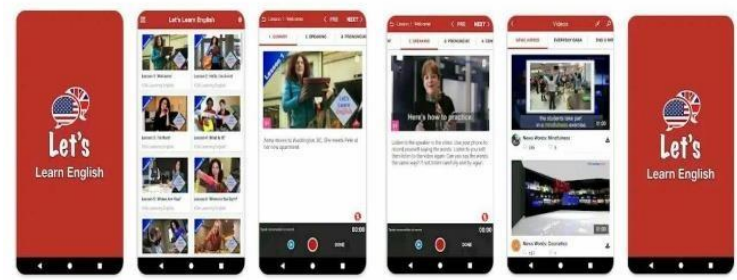

Source:

https://play.google.com/store/apps/details?id=c $\underline{\text { om.latmobile.letlearnenglish }}$

\section{METHOD}

This type of research was experimental research. This method used because the writer wants to conduct an experiment to look for the influence of independent variables on the dependent variable under controlled conditions. According to Gordon L Patzer (2018) causality is relationship in which change in one variable causes a change or effect in another variables. The first variable is referred to as the independent variable and it causes an effect on the second variable referred to as dependent variable. According to Creswell (2012) you use an experiment when you want to establish possible cause and effect between independent and dependent variables. This means that you attempt to control all variable that influence the outcome except for the independent variable.

The research method used in this research was the Quasi experimental design method. This form of experimental design was a development of true experimental design, which is difficult to implement. This design has a control group, but it cannot function fully to control external variables that influence the execution of the experiment. Nevertheless, this design is better than pre-experimental design. Quasi experimental design used because in reality it is difficult to get a control group used for research.

The research design used is Nonequivalent Control Group Design, In this design there are two groups chosen randomly. This design uses two groups (control group and experiment group). Control group using conventional method, meanwhile, experiment group using role playing learning model based android. Population in this research at the tenth grade students of SMK Yaumin Cikande 
Universitas Banten Jaya

consist of 40 students. The writer used two class, namely: control class and experiment class. Each class there were 20 students

\section{DISCUSSION}

SMK Yaumin Cikande is one of school located in Pabuaran Cikande, kec. Cikande Kab. Serang Prov. Banten. The reason of the writer choose SMK Yaumin Cikande is because the problem of learning English, especially in speaking skills taught in the class is less effective because the learning model used was monotonous and does not attract students. Students are not motivated to learn English but on the other hand, students found it difficult to speak English. In this case, the learning model applied to overcome these problems is an androidbased role playing learning model in class $\mathrm{X}$ TKR and TKJ classes at SMK Yaumin Cikande have class of 5 classes with a total of 124 students.

Description of the data that would be presented from the results of this study is to provide a general description of the distribution of data obtained in the field. The data presented is in the form of raw data that is processed using descriptive statistical data techniques. The description of this data is presented with a frequency distribution, total average score, standard deviation, mode, median, maximum score and minimum score.
Based on the research conducted by the writer, we can find out data about students of SMK Yaumin Cikande in the academic year 2019-2020. In this study the sample used was class $\mathrm{X}$ TKJ and X TKR as many as 40 students out of 104 students, with for this purpose the 40 students were the source of data that would represent the population.

From the sample of 40 students there were two study groups, namely: control class and experimental class. First of all, the two classes were pre-test, then for the control class were treated using conventional learning models, whereas, for the experimental class were treated using an Android-based role playing learning model. Furthermore, both classes were given a post-test with an oral test of 5 questions.

Table 1.1 The following is the frequency distribution data from the pre-test and post-test results.

\begin{tabular}{|c|c|c|c|c|c|}
\hline \multirow{3}{*}{ No } & \multirow{3}{*}{$\begin{array}{c}\text { Data } \\
\text { statistic }\end{array}$} & \multicolumn{4}{|c|}{ Value } \\
\hline & & \multicolumn{2}{|c|}{$\operatorname{Exp}$} & \multicolumn{2}{|c|}{ Control } \\
\hline & & $\begin{array}{l}\text { Pre- } \\
\text { test }\end{array}$ & $\begin{array}{l}\text { Post } \\
\text {-test }\end{array}$ & $\begin{array}{l}\text { Pre- } \\
\text { test }\end{array}$ & $\begin{array}{l}\text { Post } \\
\text {-test }\end{array}$ \\
\hline 1 & Mean & 59,3 & 72,9 & 68,3 & 58,8 \\
\hline 2 & Median & 59,5 & 74,5 & 59,5 & 59,5 \\
\hline 3 & Mode & 65,8 & 70,9 & 60,5 & 69,5 \\
\hline 4 & $\begin{array}{l}\text { Min } \\
\text { score }\end{array}$ & 45 & 60 & 45 & 45 \\
\hline 5 & $\begin{array}{l}\text { Max } \\
\text { score }\end{array}$ & 70 & 85 & 70 & 70 \\
\hline
\end{tabular}


Universitas Banten Jaya

\begin{tabular}{|c|c|c|c|c|c|}
\hline 6 & Variants & 40,7 & 76,4 & 93,4 & 55,9 \\
\hline 7 & $\begin{array}{l}\text { Standard } \\
\text { deviation }\end{array}$ & 6,38 & 8,74 & 9,66 & 7,48 \\
\hline
\end{tabular}

\section{Figures 1.1 The improvement of students} speaking skill

\begin{tabular}{|c|c|c|c|}
\hline $\begin{array}{r}80 \\
70 \\
60 \\
50 \\
40 \\
40 \\
30 \\
20 \\
10 \\
\\
0\end{array}$ & $\overline{\bar{z}}$ & 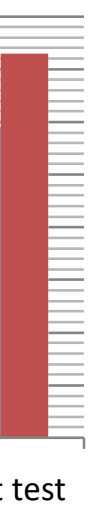 & $\begin{array}{l}\text { control class } \\
\text { experiment } \\
\text { class }\end{array}$ \\
\hline & $\begin{array}{l}\text { Pre- } \\
\text { test }\end{array}$ & $\begin{array}{l}\text { Post- } \\
\text { test }\end{array}$ & Improvement \\
\hline - Control & 68,3 & 58,5 & $-9,5$ \\
\hline Exp & 59,3 & 72,9 & 13,7 \\
\hline
\end{tabular}

\section{a) Normality Test}

The technique used for the normality test is to test Lilliefors because it uses group data, with a significant level of $a=$ 0.05 to test the hypothesis. Normality test aims to determine whether the research data is normally distributed or not, because in statistical statistics normal data distribution is a must and is an absolute requirement.

\section{a) Experiment class}

Based on the results of the Lilliefors test using SPSS that for the pre-test results of the learning skills of the control class students ware 0,375 significant value 0.375
$>0,190$ then the research data are normally distributed.

Meanwhile, for the post-test based on the results of the Lilliefors test was 0,197 significant value $0.197>0,190$ then the research data ware normally distributed.

\section{b) Homogeneity Test}

Based on the calculation of normality, the result that all data in pre-test and posttest of both experiment class and control class have been distributed normality. The next step of the calculation was finding the homogeneity of the data. The purpose of this calculation was to see whether the data or sample in both classes was homogenous or heterogonous. In this research used SPSS to homogeneity test with significant $a=$ 0,05 .

Based on the results of homogeneity calculations for pre-test (control class and experiment class) that obtained values of 0,837 significant value $0.837>0.05$ then the research data were homogeneous. While, based on the results of homogeneity calculations for post-test (control class and experiment class)that obtained values of 0,591 significant value $0,591>0.05$ then the research data were homogeneous.

\section{c) Hypothesis test}

The hypothesis test used in this study is a comparative hypothesis test with a t test with a significant level of $\mathrm{a}=0.05$ because it used pre-test and post-test data. 
$\mathrm{T}$-table from the distribution table $\mathrm{t}$ for $\mathrm{a}=$ 0.05 with $\mathrm{dk}=\mathrm{n} 1+\mathrm{n} 2-2=38$ then $\mathrm{t}$-table $=2.06$ because $\mathrm{t}$-count $>\mathrm{t}$-table $(5.35>2.06)$ then $\mathrm{H} 0$ rejected, which means at the $95 \%$ confidence level there is the influence of the Android-based role playing learning model towards student's motivation in speaking skills at 10th grade at SMK Yaumin Cikande.

\section{CONCLUSION}

Based on the finding and discussion, it could be concluded that use of androidbased role playing learning model as model in teaching of speaking skill was influence. It can be seen after four meetings treatment of both experiment and control class, the result showed than the mean of improvement score in experiment class which was given android-based role playing learning model is 13,70 . Meanwhile on the post-test results the control class actually decreased by -9.55 . It means that the mean of improvement score in experiment class is higher than control class.

Based on the calculation of reliability using SPSS obtained questionnaire for experiment class after using android-based role playing learning model obtained ri = 0,844 and based on the classification criteria reliability value $\mathrm{ri}=0,844$ is between $0,80<1,00$, then for five questions have very high reliability. That means students' motivation in speaking skills increases after applying an Android-based role playing learning model by using the Let's Learn English application.

Then, the results of testing the hypothesis by t test at a significant level $a=$ 0.05 with $\mathrm{df}=38$ obtained t-table $=2.06$, for the results of t-count obtained from questionnaire calculations and post-test experimental class using the formula $\mathrm{t}$ $=\frac{X A-X B}{S_{g a b} \sqrt{\frac{t}{n A}} \frac{1}{n B}}$ obtained $\mathrm{t}$-count $=5,35$ because $\mathrm{t}$-count $>\mathrm{t}$-table $(6.44>2.06)$ then $\mathrm{H}_{0}$ is rejected and $\mathrm{H}_{\mathrm{a}}$ is accepted, which means at $95 \%$ confidence level There is the influence of based-android role playing learning model toward students' motivation in speaking skill at $10^{\text {th }}$ grade at SMK Yaumin Cikande. In addition, in the calculation of the coefficient of determination there is a variable $\mathrm{X}$ effect on the variable $\mathrm{Y}$ by $53 \%$, the remaining $47 \%$ is influenced by other outside variables.

\section{REFERENCES}

\section{a. Source from text book:}

Anne, Burn. (2010). Doing Action Research in English Language Teaching: A guide for Practitioner. New York: Routledge.

Gay, L. R., Geoffrey E. Mills, Peter W.

Airasian. Education Research Competencies for Analysis and Applications. United States of 
Universitas Banten Jaya

America:Pearson Education. 2012. $10^{\text {th }} \mathrm{Ed}$.

Harmer, Jeremy. The Practice of English

Language Teaching. England:

Longman, 2007.3 $3^{\text {rd }} \mathrm{Ed}$.

Hwang, Gwo-Jen., Chih-Hung Chen.

Influences of an inquiry-based ubiquitous gaming design on students' learning achievements, motivation, behavioral patterns, and tendency towards critical thinking and problem solving. British Journal of Educational Technology Volume 48, Issue 4, May 2016.

Hyland K,. (2003). Second language Writing. Cambridge: Cambridge University Press

Ladousse, Gillian Porter. Role Play.Oxford:

Oxford University Press. 2000.

Leong, Lai-Mei, Seyedeh Masoumeh

Ahmadi. An Analysis of Factors Influencing Learners' English Speaking Skill. International Journal of Research in English Education (IJREE).2017.

Majid, Abdul. Strategi Pembelajaran. Bandung: PT Remaja Rosda karya, 2016.

Maolani, Rukaesih A., Ucu Cahyana. Metodologi Penelitian Pendidikan. Jakarta: PT Raja Gravindo Persada. 2015. $1^{\text {st }} \mathrm{Ed}$.

\section{d. Thesis and dissertation}

Margianty, Eka. Teaching Speaking Using Role Play Technique. 2012. NCRLC The Essential Language Teaching. Teaching Speaking: Goals and Techniques for Teaching Speaking. 2014.

Muria, Marianne Celce. Teaching English as a Second Language or Foreign Language. Boston: Heinle and Heinle Publishe. 2012.

\section{e. Journal}

Clark, Herbert H. Using Language. New York: Cambridge University Press. (2012)

Doff, Adrian. Teach English: a Training Course for Teachers. Cambridge: the Press Syndicate of the University of Cambridge. 2004.

Fauzi, Dendy Luth fan. Pembangunan Aplikasi M-Commerce Layanan Jasa Jahit Berbasis Mobile Hybrid Menggunakan Ionic Framework. 2018.

Gebhard, Jerry G. Teaching English as a Foreign OR Second Language: a teacher self-development and methodology guide. United Stated of America:The University of Michigan Press. 2006.

Kayi, Harriye. Teaching Speaking: Activities to Promote Speaking in a Second Language.The internet TESL 
Universitas Banten Jaya

Journal, Voll. XII, No. 11, November 2014.

Liu, Feng., Yun Ding. Role Play in Eglish Language Teaching. The internet CCSE Journal, Vol. V, No. 10, October 2009.

Maiyana ,Efmi. Utilization of Android in the Design of Prayer Collection Applications. Research of Science and Informatic V4.I1 (54-67) 26-04 2018.

Nuraida, Ida. The Effectiveness of Applying Mind Mapping Strategy On Student Speaking Ability. International Prosiding (ISQAE). 2016.

Prastya, Ilham.Skills According to Experts and Skills Needed. 2019

Putra.History, Strengths \& Version of the Android Operating System. 2019

Richards, Jack C., Willy A. Renandya. Methodology in Language Teaching. Cambridge: Cambridge University Press. 2002.

Santosa ,Rochmat Budi. Motivasi Dalam Pembelajaran Bahasa Inggris. Jurnal Ilmiah DIDAKTIKA Agustus 2017 VOL. 18 , NO. 1, 87-102

Saptono, L. The Implementation of RolePlaying Model in Principles of Finance Accounting Learning to Improve Students' Enjoyment and Students' Test Scores. The Journal of
Accounting and Finance, Vol. 12, No.

2, November 2010: 71-81.

Savignon, Sandra J. Communicative

Competence: Theory and Classroom

Practice: Texts and Contexts in

Second Language Learning. United

States of America:

The McGraw-Hill Companies, Inc, Second Edition. 2012. Troussas, Christos, AkriviKrouska, CleoSgouropoulou. Collaboration and fuzzy-modeled personalization for mobile gamebased learning in higher education. Journal of Computer and Education, Vol. 114, No. 10, January 2015.

Yanto, Ari. Role Playing Method To Improve Student Learning Results On IPS Subject. Journal of Cakrawala Pendas, Volume I, No. $1^{\text {st }}$ January, 2015.

\section{f. Internet}

The Application of Let's Learn English https://play.google.com/store/apps/det ails?id=com.latmobile.letlearnenglish 
